\section{FEATURE}

Graeme Chamberlin

\section{Office for National Statistics}

\section{SUMMARY}

Until recently, the private non-financial corporations sector was a fairly large net lender to the rest of the UK economy, reflecting relatively high gross savings and weaker capital investment. This article investigates some of the factors accounting for these trends and why this position is now beginning to reverse.

\title{
Recent trends in UK corporate net lending
}

$\mathrm{n}$ recent years the private non-financial corporations (PNFC) sector has been a net lender to the rest of the economy. This means that the earnings of corporations have exceeded payments, such as dividends to shareholders and spending on capital equipment. Excess corporate funds are therefore available to support spending in other sectors of the economy, particularly households and government, which at the same time have increasingly become net borrowers. These trends are evident from Figure 1.

The focus of this article is an attempt to explain why UK firms have been accumulating cash, and why this trend is now beginning to reverse. It should be made clear at the outset that this is a purely analytical piece and that the points raised should not necessarily be considered a definitive explanation of the data. Instead, the article simply reflects the author's thoughts on these questions and how the evidence might be interpreted.

General government net borrowing mainly reflects movements in the current budget balance, which has predominately been in deficit over the last two decades. The government's fiscal rules imply the current budget will be close to balanced over the economic cycle. If this is to be maintained, net borrowing, excluding that used to fund long-term investment, should be close to zero over the medium term. There is some evidence of this from Figure 1, observing the period from 1997 onwards. Initial budget surpluses corresponding to net lending have given way to budget deficits corresponding to net borrowing for the general government sector.

The household sector is traditionally a net lender to the rest of the economy, but has increasingly become a net borrower since the new millennium. It is tempting to blame growing indebtedness on excessive consumer spending supported by easy access to cheap credit. However, apart from a brief period between 1996 and 1999, consumer expenditure has grown

\section{Figure 1}

Net lending of household, government and private non-financial corporations as a proportion of GDP

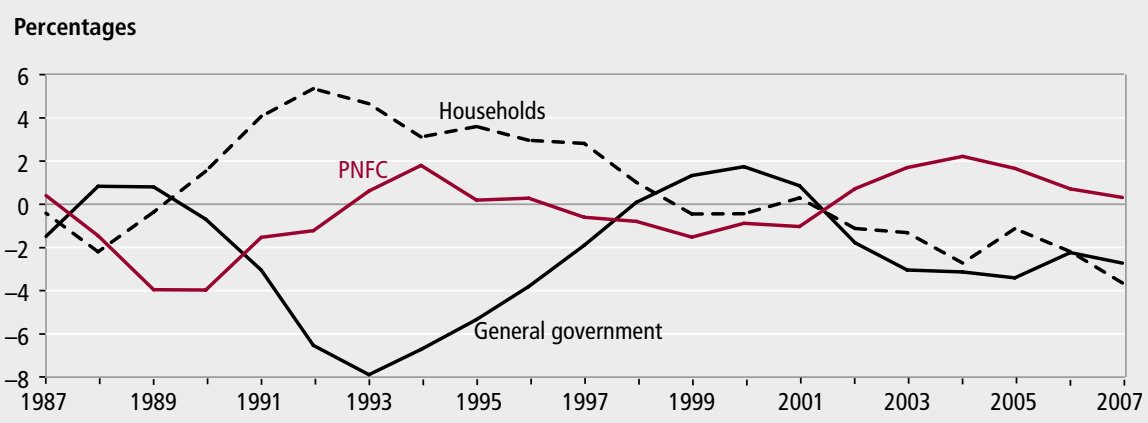


at rates close to its long-term average. Although unsecured consumer debt has increased as a proportion of disposable income, it actually accounts for a relatively minor part of households' accumulation of financial liabilities. In fact, households have remained net borrowers despite a diminishing appetite for consumer loans and a tightening in credit availability during the last two years. Growing net borrowing seems more likely due to secured (mortgage) borrowing linked to the recent episode of strong house price inflation.

It is interesting that the circular flow of income in the UK economy is moving in the opposite direction to that expected by conventional wisdom. Economists are used to a situation where financial institutions perform an intermediary role, channelling savings from the household and overseas sectors to domestic or foreign corporations in order to fund long-term investment. Figure 1 demonstrates that recent experiences are running contrary to this view, as businesses have been lending to households.

Nor has this phenomenon been unique to the UK. The International Monetary Fund (2006) has recently presented similar trends for other G7 nations. Without this source of saving to offset the increase in borrowing from the household and government sectors, the extent of global imbalances might be more worrying. For example, in the US it is calculated that saving from the corporate sector has offset around 50 per cent of consumer and government borrowing. Without this, current levels of consumer and government spending would require further borrowing from overseas, a result that would manifest itself in a larger current account deficit, extenuating the already weak external position of the US economy and fears of a hard landing.

Similar concerns exist for the UK economy, which has also experienced a prolonged rise in its current account deficit. Without the net lending of the PNFC sector, and the substantial net lending of the financial sector which is not shown in Figure 1, the UK's external position would be weaker still. These patterns may of course be partly a cyclical phenomenon. As the UK economy begins to slow, corporate net lending would be expected to fall in line with profits, and the household sector becomes less of a net borrower as saving rises.

Positive net lending basically arises when the gross saving of firms exceeds their capital expenditure:

net lending/borrowing $=$ gross saving - capital spending

\section{Figure 2}

\section{Net lending of the UK PNFC sector and its components as a proportion of GDP}

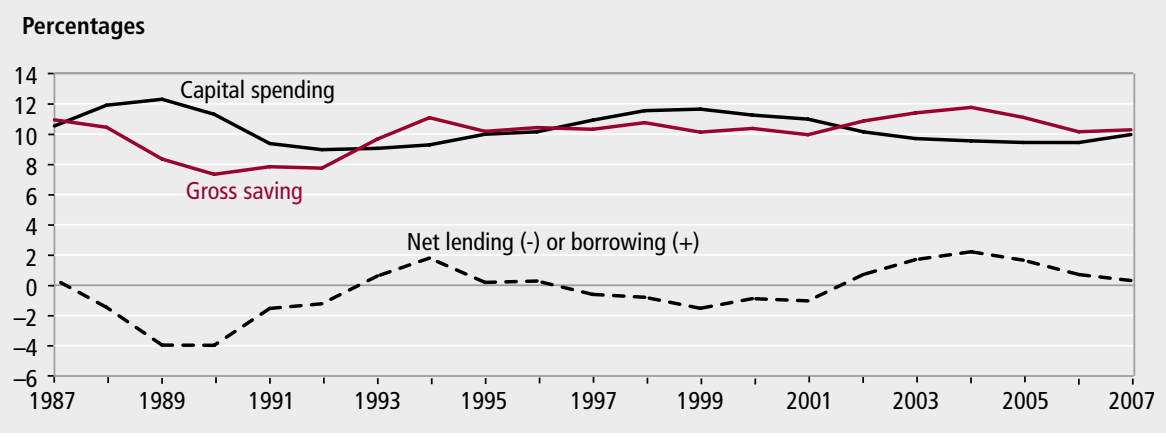

Figure 3

\section{Gross saving of the UK PNFC sector and its components as a proportion of GDP}

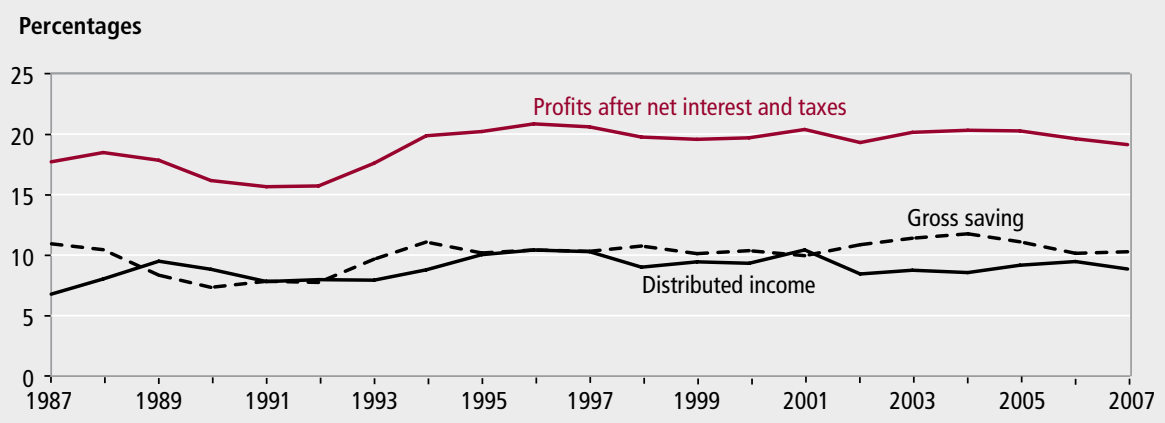

Gross saving is retained profits that represent the undistributed internally generated funds available for investment. If the sector as a whole were a net borrower, it would imply that internally generated funds were insufficient to meet planned capital expenditures, hence necessitating the use of external funds.

As Figure 2 shows, the sector became a net lender after 2000 due to a combination of a rise in the gross saving rate, and a fall in the ratio of capital expenditure to gross domestic product (GDP). In the last two years, PNFC net lending as a proportion of GDP has fallen, mainly due to a declining corporate saving rate, but also due to a slight increase in capital expenditure in 2007.

Therefore, trends in PNFC net lending can be accounted for by movements in these two components. The weakness of UK investment over this period, despite a favourable environment, has surprised many policy makers and has been widely discussed (see Grieve 2006). Movements in the corporate gross saving rate have, though, attracted less attention. The structure of this article analyses these components in turn before some summary remarks.

\section{PNFC gross savings}

Gross savings are defined as the undistributed earnings of companies thus:

profits after taxes and net interest - dividends paid

Looking at Figure 3, it is clear that, between 2001 and 2005, profits after net interest and taxes were fairly constant as a proportion of GDP. Therefore, the trend in the corporate gross saving rate in this period was predominately driven by a tendency to reduce the relative share of dividend payments. In the last two years, a decline in the corporate saving rate seems to reflect a slight rise in dividend payments and a fall in profits after net interest and taxes.

Profits after net interest and taxes can also be broken down into its constituent parts as:

\section{gross operating surplus + property} income - net interest paid - taxes

As seen in Figure 4, gross operating surplus has picked up slightly since the new millennium, but the trend is not significant and the series remains close to average historical proportions of GDP. The interesting feature of PNFC profits is 
Figure 4

\section{Earnings of the UK PNFC sector as a proportion of GDP}

\section{Percentages}

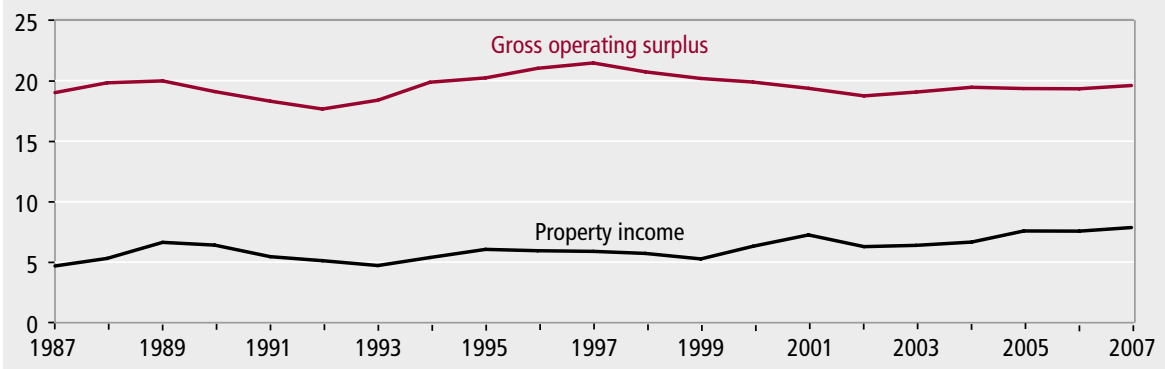

Figure 5

PNFC net accumulation of financial assets as a proportion of GDP: by asset type

Percentages

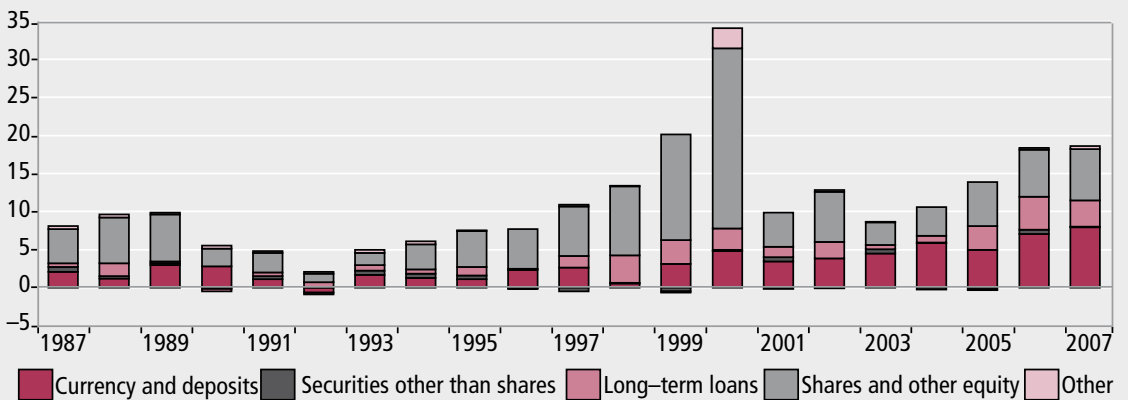

Figure 6

PNFC stocks of asset holdings as a proportion of GDP: by type of asset

\section{Percentages}

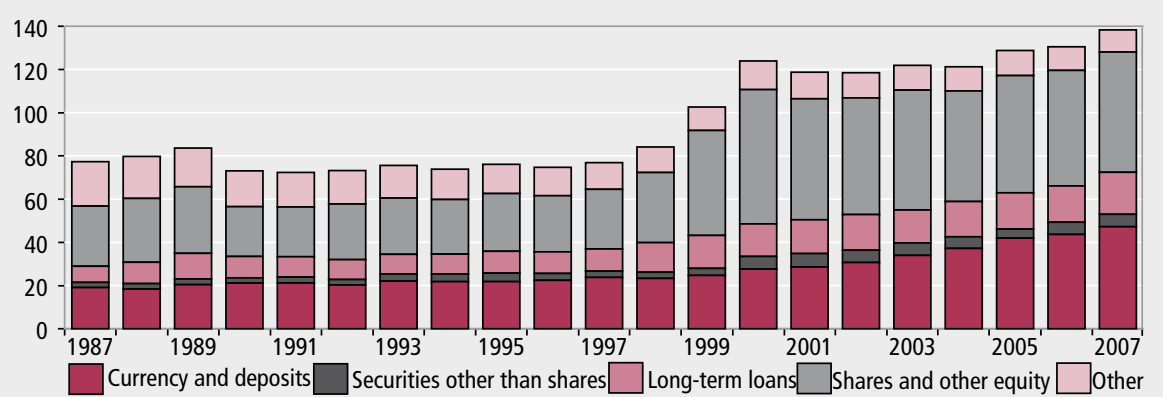

\section{Figure 7}

\section{PNFC accumulation of shares and equities as a proportion of GDP: by} origin

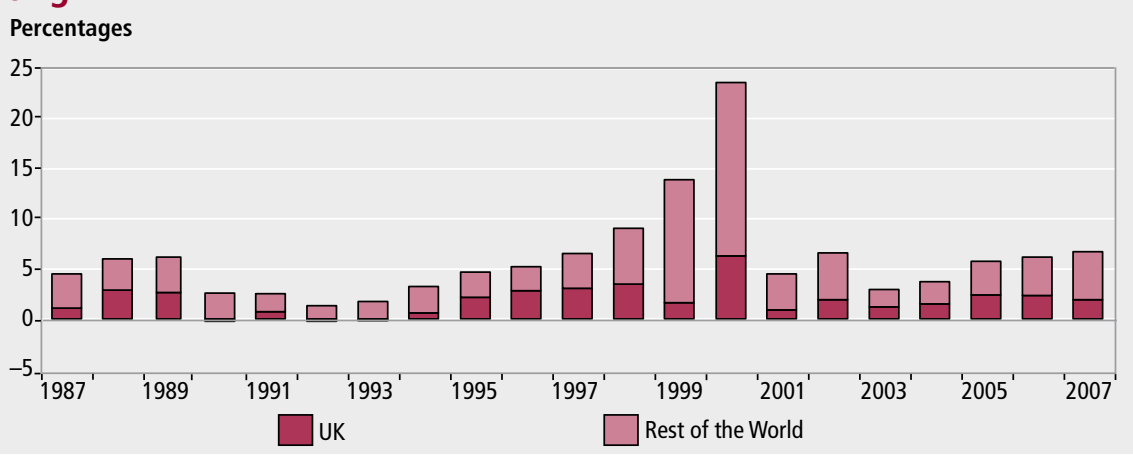

the increasing proportion derived from property income, referring to corporate earnings from equity holdings and foreign direct investment.

The rise in property income since 2000 is in line with the large accumulation of shares and equity by the PNFC sector in the late 1990s (see Figure 5). As a result, there was a step change in the stock of financial assets held by this sector as proportion of GDP (Figure 6).

Therefore, growing property income is simply reflective of the trends in the accumulation and stocks of shares and equities held by private companies. It is not that surprising that more assets generate more income. One of the most notable trends in the accumulation of shares and equity is that most of it is in foreign rather than UK assets, so a large proportion of the increase in property income is being generated overseas. This is shown in Figure 7 and Figure 8.

This is consistent with recent trends in the balance of payments, where the UK has been generating positive investment income flows despite persistent current account deficits, leading to a deteriorating net asset position (also known as the international investment position). Nickell (2006) accounts for the UK's ability to generate positive income from a negative position, as it has been operating like a successful venture capitalist, accumulating low-return interest-bearing liabilities while accumulating high-return direct investment assets (foreign direct investment not only includes direct purchases of foreign capital, but also significant (greater than 10 per cent) equity takes in foreign companies).

But, as shown in Figure 9, the increase in company earnings has been increasingly offset by an increase in tax and interest payments (particularly the latter). Much of the accumulation in equities during the end of the 1990s was funded by interest-bearing debt, hence there has been a corresponding increase in financial liabilities, and companies have generally become more highly leveraged. When combined with the recent tightening of monetary policy, interest payments have risen quite sharply for the PNFC sector, reaching the proportions of GDP seen in the highinterest rate era of the late 1980s and early 1990s. Furthermore, the current episode of low inflation means debt repayment may actually be at historical highs in real terms as inflation erodes the value of nominal debt. This appears to be the main factor driving down PNFC gross saving.

As company profits net of interest and tax 


\section{Figure 8}
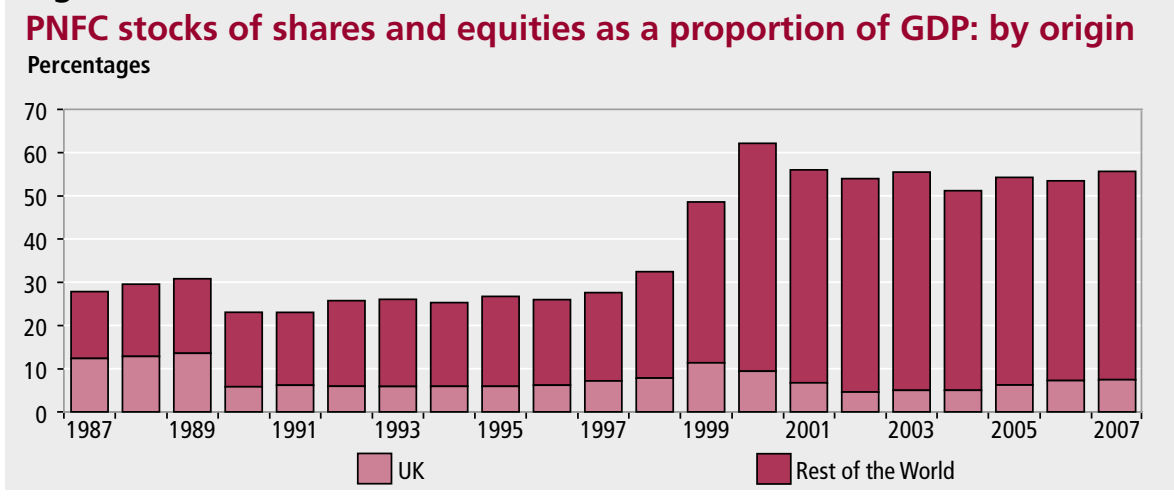

\section{Figure 9}

\section{PNFC net interest and taxes as a proportion of GDP}

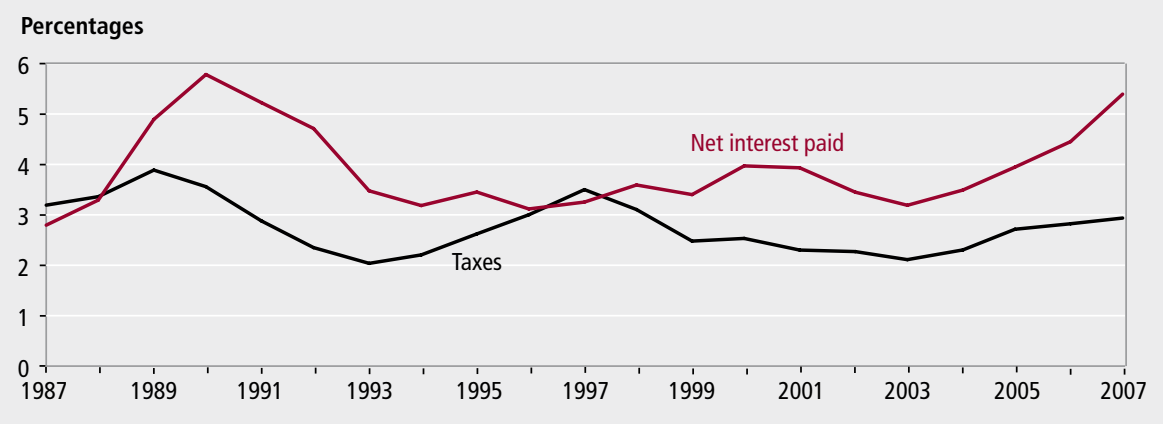

payments remained fairly stable between 2001 and 2005, the rise in the gross saving rate during this period predominately reflected the fall in the share of dividend payments. Given that corporate profitability has remained fairly robust, this cannot be attributed to a falling share of profits in GDP. Also, given the evidence in Figure 2, it does not seem to be the case that dividends are being squeezed to increase the internal funds available for capital spending.

One explanation is that companies are returning money to shareholders through means other than dividend payments. This is typically achieved by a company repurchasing its own shares, often at a premium. For most shareholders, capital gains taxes are lower than their marginal rate of income tax, so it represents a tax efficient way of distributing money. It is also consistent with managerial incentives, as maintaining high stock prices increases the value of stock options. Although there is some evidence of increasing use of share buy-backs in the US, there does not appear to be much evidence that it is a significant factor in the UK.

An alternative explanation is that firms cut dividends in order to build cash holdings. There are several reasons why this might be beneficial, some of which will be discussed in more detail later in the article. But an important consideration may have been the need to make cash contributions to fill deficits in company-sponsored defined benefit (DB) pension schemes. Here, employees are entitled to a stream of pension benefits deriving from a formula that typically lends itself to salary and years of service. The liabilities and assets of DB pension funds have been sensitive to equity market values and life expectancy assumptions, with important implications for corporate balance sheets.

The 1995 Pensions Act specifically introduced the minimum funding requirement, broadly stating that, every three years, trustees of DB schemes must obtain a minimum funding valuation stating how scheme assets compare with scheme liabilities. The calculations are made on the assumption that, if the fund were to be wound up, there are sufficient funds to buy out pensioner benefits with an insurance company and provide nonpensioners with a fair actuarial value of their accrued rights, which can be transferred to an alternative pensions vehicle. When schemes fall short of 90 per cent funding, the employer is required to make up the shortfall to 90 per cent within three years, as well as agreeing to contribution rates sufficient to achieve the full 100 per cent level within ten years. There is also a fiscally enforced limit to prevent overfunding beyond 5 per cent of projected obligations. Any surplus above 105 per cent of liabilities has to be eliminated by benefit improvements, reduction in employer and/or employee contributions, or a taxed payment from the scheme to the employer.

The funding position of DB schemes has been very sensitive to equity price movements. Strong stock market performance in the late 1990s swelled the net asset position of funds, enabling firms to reduce the contributions necessary to meet their obligations. However, the subsequent fall in stock markets as the 'dot-com bubble' unwound, coupled with upward revisions to life expectancy, has reversed this position, with many schemes becoming underfunded. In response, there has been an acceleration in employer pension contributions.

Pension fund deficits could be corrected by providing less generous terms, with many firms having closed DB schemes to new members, and some even to existing members, as they look to remove the risks of asset price volatility and uncertainty over life expectancies from their balance sheets. However, it is difficult for firms to change contractually agreed pension arrangements quickly, and many still need to offer an attractive pensions scheme to attract the best-quality workers in competitive job markets.

The effects of higher pension contributions on corporate expenditure have been investigated by Bunn and Trivedi (2005) using evidence from UK company accounts. Results from their econometric analysis suggest the main impact of higher pension contributions is on dividend payments rather than on investment, where the downward effect has been relatively minor. These results are not generally surprising. As Pomerantz and Weale (2005) argue, the easiest way to solve a pensions deficit would be to fully exploit those profitable opportunities available rather than limiting earnings. Those investment projects profitable at the margin should not be deterred by the need to make pensions contributions.

They also go on to argue that it is difficult to see why funding pensions deficits should create a general shortage of financing. Perhaps firms would be unwilling to invest pension funds in their own parent company, but all pension funds have to be invested somewhere, so collectively the need to top up funds should not necessarily be restricting the PNFC sector of funds. If, as widely believed, pension funds have shifted their funds away from equities towards fixed interest securities, one would expect that the resulting low rates of interest would 
induce companies to rely rather more heavily on loan finance than share issues. Therefore, the portfolio decisions of pension funds should not also impact too greatly on the availability of finance.

Making pensions contributions could have a negative effect on capital expenditure by forcing companies to rely more heavily on relatively expensive external financing. However, there is also an offsetting effect on the cost of capital. Most credit-rating agencies take pension fund shortfalls into account, so while funding a deficit with cash contributions will reduce the availability of cheaper internal finance, it also lowers the risk premiums associated with offbalance sheet liabilities. In reality, there are incentives to respond to deficits other than the regulatory enforcements.

In the last two years, the recovery in equity markets along with significant restructuring in, and closure of, $\mathrm{DB}$ pension schemes has seen the aggregate pension deficit of the UK's largest companies fall. Given the findings of Bunn and Trivedi, this might account for the slight rise in dividend payments made by the PNFC sector more lately.

\section{PNFC capital expenditure}

This section looks at the other side of the PNFC net lending situation - the relative weakness of UK corporate investment.

Explaining this concept can be hard because most of the traditional indicators and the general economic environment have been very supportive. The conclusion is that something more structural is at work. Here, two possibilities are discussed: that weak capital spending is a nominal rather than a real issue; and that, in line with structural change in the economy, the definition of what constitutes investment has changed from the tangible to the intangible.

Because of falling relative capital goods prices, the weakness in PNFC investment appears to be a nominal rather than a real phenomenon. Figure 10 plots the deflators for GDP and gross fixed capital formation, which clearly shows that capital goods prices have grown at a much slower rate than the other components of demand. The consequence, as displayed in Figure 11, is that the share of PNFC capital expenditure in GDP looks rather low in nominal terms, but not so bad in real terms.

Therefore, a simple explanation for PNFC net lending is that firms do not have to spend as much (relative to GDP) to achieve their optimal capital stocks. In fact, because most capital goods prices are not adjusted for quality changes, the divergence between nominal and real capital spending might be even greater in actuality.

It is commonly asserted that the weakness of business (PNFC) investment is a consequence of firms spending increasing amounts on goods and services

\section{Figure 10}

\section{GDP and capital goods deflators}

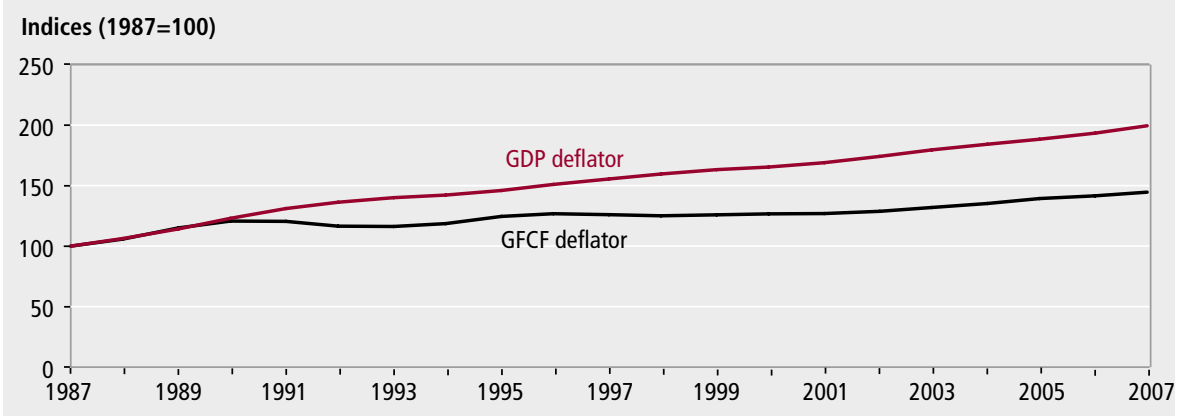

\section{Figure 11}

\section{PNFC capital expenditure as a proportion of GDP}

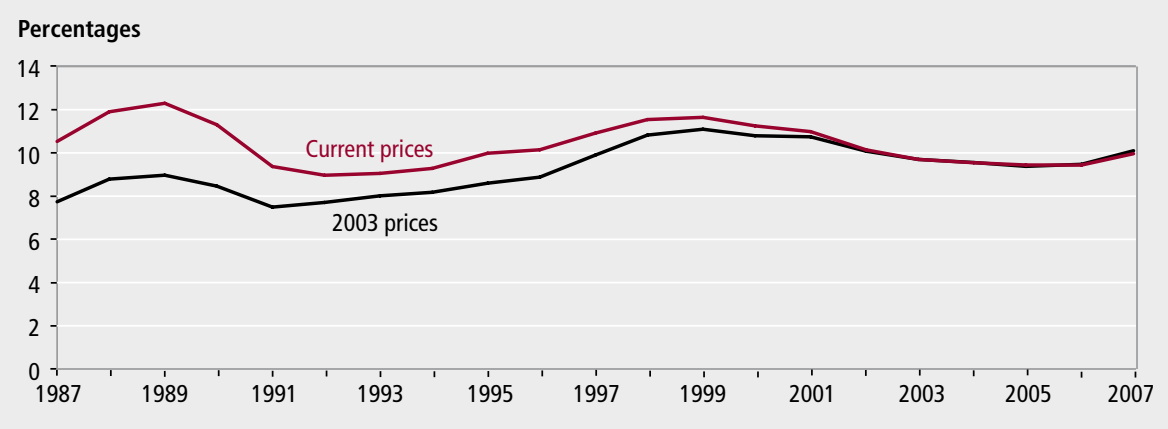

that national accountants do not recognise as capital assets. These are the so called intangible products, which do not have the characteristics of traditional plant and machinery but, because they yield a flow of future returns to the business, are deemed to have asset properties. The significance of these assets has grown as the UK economy continues to move away from manufacturing towards services; this is also due to the increasing incidence of new information and communication technologies.

It is wrong to criticise statisticians for completely failing to recognise these important structural developments. The National Accounts have recently been expanded to recognise software as a capital good, even recording that produced inhouse known as own-account software (Chamberlin et al 2007). In the future, firm spending on research and development (R\&D) could also be treated as capital rather than current expenditure, initially in satellite accounts and then possibly in the full set of National Accounts (GalindoRueda 2007). However, work undertaken by researchers at Queen Mary College and HM Treasury argues that this still remains too narrow an interpretation (Giorgio Marrano et al 2007). The stock of intangible assets developed by firms should also include their brands, the human capital of their work forces and their organisational structure and management.

Estimates of these intangibles are shown in Figure 12. Software investment also incorporates spending on computer consultancy. The main components of non-scientific R\&D are copyright licences, financial innovation and new products, architecture and engineering design. Conventional scientific R\&D is expanded to include mineral exploration. Investments in brand equity include proportions of advertising and market research expenditures. Finally, organisational structure or firm competencies predominantly consist not only of training expenditures, but also of management consultancy.

These categories of spending are a nontrivial and growing proportion of GDP. Accepting this much broader interpretation of capital would significantly increase the share of private sector investment in GDP and reverse the longer-run downward trend, although not the fall in recent years (see Figure 13).

The intangibles story might go some way to answering the puzzle of PNFC net lending. First, the weakness of capital 
expenditure is a matter of definition. A wider interpretation, in line with structural changes in the UK economy, would significantly increase the investment share of GDP. Second, as it is probably difficult to fund intangible investment with external finance such as bank loans, it might also explain why firms are looking to increase internal funds by restricting other capital expenditure or dividend payments.

It is not clear cut though that many of the intangibles identified by this study will be universally accepted as investment expenditure, especially because they would be tough to both rigorously define and measure. While investigating expenditure on more intangible products might be interesting in the light of structural changes in the UK economy, there can still be a gap between the methods used to analyse and measure the economy. Furthermore, accepting the intangibles argument raises a further puzzle. It is not obvious why tangible and intangible investments should be strict substitutes for each other. In fact, one might argue that the impact of education, software and R\&D makes conventional investment more, rather than less, attractive. So the ongoing weakness of corporate investment as a share of GDP is perhaps not fully answered by the intangibles story.

\section{Conclusion}

The UK PNFC sector has emerged as a net lender to the rest of the economy due to a fall in the relative shares of capital expenditure and dividend payments compared with profits after interest and taxes. To a certain extent, it is difficult to conclude whether firms have accumulated cash automatically due to the aforementioned weakness of dividends and investment, or whether the need to increase cash holdings has depressed dividends and capital spending. The answer could, of course, be a bit of both.

There is little evidence that the weakness of dividends is the result of firms distributing cash to shareholders by other means. The case for weak capital spending, that falling capital goods prices and a shift from manufacturing towards services has lowered the amount spent on traditional investment goods is more plausible.

There are numerous reasons why firms may wish to increase cash holdings. Increasing cash holdings, despite its low rate of return, is not necessarily inconsistent with maximising shareholder value. Cash is the most liquid of financial assets, so its benefits are greater when firms are faced with an increasingly uncertain world. Volatility in financial markets, inflation in energy prices, pension fund deficits, globalisation, the weakness of

\section{Figure 12 \\ Estimates of market sector intangible investment as a proportion of GDP}

\section{Percentages}

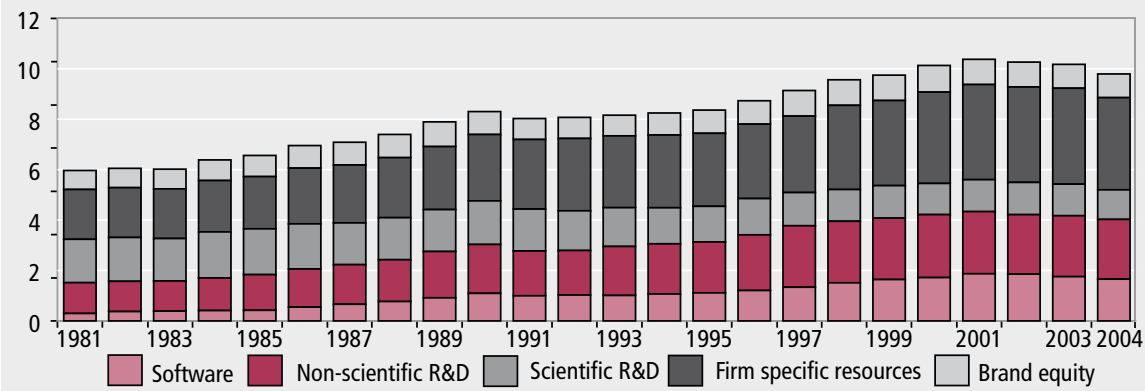

Figure 13

\section{Business investment as a proportion of GDP: extending the National} Accounts to include intangibles

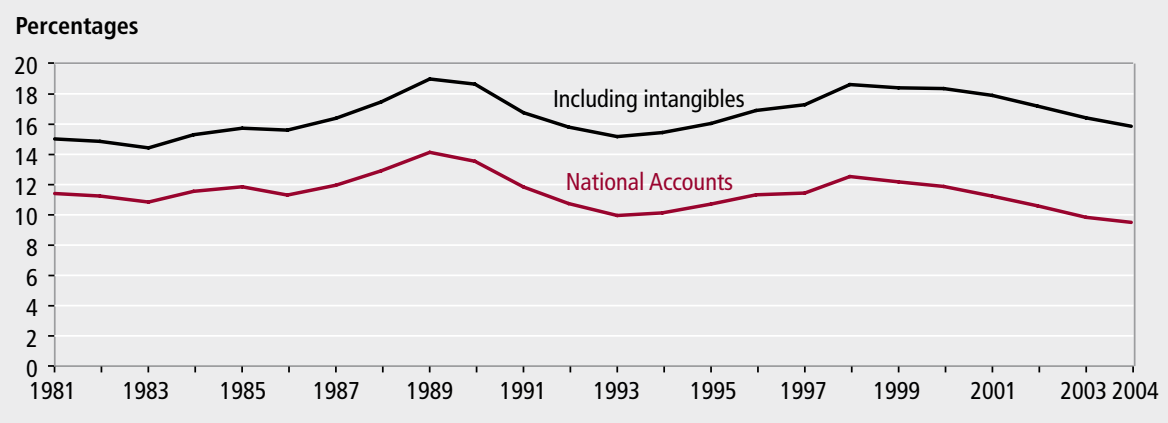

the US economy, and a global tightening of monetary policy are all risks and uncertainties that have emerged in recent years. Holding cash reduces the probability of being short of finance if profits fail to meet expectations, reducing the need to cut investment, cut dividend payments or having to rely on more expensive external finance. Furthermore, lower interest rates by historical standards have reduced the opportunity cost of liquidity.

PNFC net lending, though, has fallen in the last two years, mainly due to lower gross saving, as tighter monetary policy, combined with high leverage, has sharply increased the cost of servicing debts. The outlook indicates that this trend will continue and that the PNFC sector will once again become a net borrower, as an economic moderation or downturn weighs on operating surpluses.

\section{CONTACT}

(a) elmr@ons.gsi.gov.uk

\section{REFERENCES}

Bunn P and Tevedi K (2005): Corporate expenditures and pension contributions: evidence from UK company accounts. Bank of England working paper no. 276.

Chamberlin G, Clayton T and Farooqui S (2007) 'New measures of private sector software investment', Economic \& Labour Market Review 1(5), pp 17-28.

Galindo-Rueda F (2007) 'Developing an R\&D satellite account for the UK: a preliminary analysis', Economic \& Labour Market Review 1(12), pp 18-29.

Giorgio Marrano M, Haskel J and Wallis G (2007) 'What happened to the knowledge economy? ICT, intangible investment and Britain's productivity record revisited',

Department of Economics working paper no. 603, Queen Mary, University of London.

Grieve J (2006): 'The puzzle of UK business investment', Speech at the University of the West of England on 26 September 2006.

International Monetary Fund (IMF) 2006 'Awash with cash: why are corporate savings so high?', World Economic Outlook, Spring.

Nickell S (2006) 'The UK current account deficit and all that', Bank of England mimeo.

Pommeratz $\mathrm{O}$ and Weale M (2005) 'Are we saving enough? The macroeconomics of the savings gap', National Institute Economic Review, pp 79-92. 